\title{
Pengaruh Konservatisme Terhadap Efisiensi Investasi Dan Agency Cost Sebagai Variabel Moderasi Pada Perusahaan Yang Melakukan Merger Dan Akuisisi Di Asia Tenggara
}

\author{
Dina Juliani dan Ratna Wardhani \\ Fakultas Ekonomi dan Bisnis, Universitas Indonesia \\ dina.juliani@gmail.com
}

\begin{abstract}
This research aim to exmine the effect conservatisme on investment efficiency and agency cost as moderating variable. This research is conducted on public companies doing megers and acquisitions in Indonesia, Singapore, Malaysia, Vietnam, Philippines and Thailand from 2012-2016. The results show that conservatism has a positive effect on investment efficiency and agency cost strengthens the positive influence of conservatism on investment efficiency
\end{abstract}

Keywword: conservatism, investment efficiency, agency cost

Abstrak: Penelitian ini bertujuan untuk menguji dampak konservatisme terhadap efisiensi investasi dan agency cost sebagai variabel moderasi. Penelitian ini dilakukan pada perusahaan publik yang melakukan merger dan akuisisi di Indonesia, Singapura, Malaysia, Vietnam, Filipina dan Thailand pada tahun 2012-2016. Hasil penelitian menunjukkan bahwa konservatisme berpengaruh positif pada efisiensi investasi dan agency cost memperkuat pengaruh positif dari koservatisme terhadap efisiensi investasi.

Kata kunci: konservatisme, efisiensi investasi, agency cost

\section{PENDAHULUAN}

Dengan adanya Masyarakat ASEAN ini perkembangan investasi perdagangan barang maupun jasa akan sangat meningkat di Negara-negara ASEAN. Perluasan usaha yang biasa dilakukan oleh perusahaan yaitu Merger dan Akuisisi. Dampak dari aktivitas ini sangat besar bagi perusahaan, jika investasi atas Merger dan Akuisisi yang dilakukan berdampak baik maka meningkatkan pertumbuhan perusahaan yang signifikan dan menciptakan nilai dan dapat berdampak buruk yaitu perusahaan dapat mengalami kerugian yang besar bagi para pemegang saham perusahaan pengakuisisi (Zhu, 2011).

Namun tidak sedikit kasus kegagalan M\&A yang terjadi. Pengambilan keputusan yang tidak optimal dikarenakan adanya masalah keagenan antara principal dan agent di perusahaan. Konflik ini muncul karena adanya asimetri informasi antara principal yaitu pemilik perusahaan dan agent yaitu manager. Konflik asimetri informasi ini mengakibatkan manager sebagai agent di perusahaan tidak selalu bertindak untuk memaksimalkan nilai bagi pemegang saham, dengan melakukan tindakan yang dapat menguntungkan priadi. Akibatkanya dalam keputusan investasi, asimetri informasi dapat mengakibatkan masalah overinvestment maupun underinvestment, sehinga perusahaan tidak mencapai tingkat investasi yang efisien.

Beberapa penelitian menunjukan hasil yang tidak konsisten akan dampak dari keputusan M\&A bagi perusahaa. Tao et al. (2017), Chakrabarti (2009), Reus dan Lamont 
(2009) menunjukan bahwa perusahaan yang melakukan cross-border acquisition mengalami kinerja jangka panjang yang baik dan menghasilkan abnormal return yang tinggi, sedangkan penelitian Ghosh (2001) menunjukan hasil bahwa tidak ada peningkatan kinerja operasi setelah dilakukannya Akuisisi.

Keputusan merger dan akuisisi menjadi sangat penting karena jikaM\&A ini tidak berhasil maka akan menimbulkan kerugian yang besar bagi banyak pihak karena berdampak terhadap kinerja perusahaan acquiring dan acquiree. Dalam keputusan investasi perusahaan dapat mengalami masalah inefisiensi. Biddle et al. (2009) perusahaan dapat mengalami underinvestment yaitu ketika perusahaan kehilangan suatu proyek yang mendatangkan NPV yang positif, dan overinvestment yaitu ketika perusahaan menginvestasikan pada proyek dengan NPV negatif

Permasalahan asimetri informasi antara manajemen perusahaan dan pemegang saham dibutuhkan mekanisme yang dapat mengatasi hal ini. Konservatisme laporan keuangan merupakan mekanisme governance yang dapat mengurangi kemampuan manager dalam melakukan manipulasi dan melebih-lebihkan kinerja keuangan perusahaan dan meningkatkan arus kas perusahaan dan nilai perusahaan (LaFond dan Watts, 2008). Dengan menurunnya kemampuan manager dalam melakukan manipulasi keuangan sehingga perusahaan dapat memberikan informasi yang berkualitas kepada pemegang saham. Godfrey (2010) menyatakan bahwa konservatisme akuntasi merupakan prinsip yang penting dalam akutansi. Perusahaan yang konservatif kerugian dapat diketahui secara tepat waktu dan pengakuan keuntungan lebih lambat. Lara et al. (2016) menyatakan bahwa dengan konservatisme tersebut kerugian dari keputusan investasi yang buruk data segera diketahui. Ketika manajer melakukan investasi pada proyek yang tidak menguntungkan maka akan segera diketahui oleh pemegang saham, dan kinerja manajer dapat dinilai buruk. Oleh karena itu dengan konservatisme diharapkan dapat mengurangi ketidakefisienan dalam melakukan investasi.

Pada penelitian ini bertujuan untuk mengetahui bagaimana pengaruh konservatisme terhadap efisiensi investasi pada perusahaan yang melakukan merger dan akuisi. Merger dan akuisis adalah keputusan investasi yang bernilai besar bagi perusahaan. Konservatisme dapat membantu perusahaan dalam mengambil keputusan merger dan akusisi yang optimal. Jika manager telalu optimis terhadap keputusan investasi merger maupun akuisisi maka kemungkinan manager mengambil keputusan dengan risiko yang besar akan semakin tinggi. Francis dan Martin (2010) menyatakan pengaruh antara konservatisme dan profitabilitas investasi dalam konteks akuisisi pentingkarena akuisisi merupakan salah satu keputusan investasi yang terbesar dan mudah diamati dan investasi ini berusaha untuk menintensifkan antara konflik keagenan antara manager dan pemegang saham pada perusahaan terbuka (Jensen and Meckling, 1976).

Selain itu penelitian ini juga menguji agency cost yang muncul dari adanya agency conflict (konflik keagenan). Menurut Francis dan Martin (2010) ada dua kondisi yang perlu dipertimbangkan karena dapat mengakibatkan tingginya agency cost yaitu asimetri informasi dan lingkungan bisnis yang volatile. Masalah asimetri informasi ini dapat memperburuk kondisi overinvestment dan underinvestment. Oleh karena itu penelitian ini juga berusaha untuk menguji bagaimana pengaruh konservatisme terhadap efisiensi investasi pada kondisi perusahaan yang mengalami agency cost yang tinggi. Penelitian ini menggunakan sampel perusahaan publik yang berada pada negara ASEAN yang melakukan aktivitas investasi Merger dan Akuisisi. Karakteristik perusahaan di asia tenggara cenderung dimiliki oleh keluarga, sehingga penelitian ini ingin menguji 
bagaiamana pengaruh konservatisme pada efisiensi investasi dengan kondisi tersebut karena perbedaan kepemilikan saham dari tiap perusahaan ini mengakibatkan masalah agensi juga berbeda.

\section{KAJIAN TEORI}

Scott (2011) menyatakan agency theory adalah bagian atau cabang dari game theory yang mempelajari desain motivasi yang berlawanan seorang agen rasional untuk bertindak atas nama prinsipal pada saat kepentingan agen bertentangan dengan prinsipal. Berdasarkan teori agensi tersebut prinsipal yaitu pemegang saham memberikan wewenangnya ke agen atau manajer untuk mengelola perusahaan dengan baik, namun hubungan antara agen dan principal adalah memaksimalkan keuntungan maka hal ini dapat menjadi suatu alasan seorang agen tidak selalu mengambil tindakan terbaik bagi pihak principal. Hal ini karena adanya motivasi yang berlawanan tidak menutup kemungkinan akan memunculkan konfik kepentingan antara agen dan principal.

Masalah agensi yang dihadapi perusahaan muncul karena para investor yang menanamkan dananya diperusahaan tidak berperan aktif dalam menjalankan manajemen perusahaan dan tanggungjawab menjalankan perusahaan didelegasikan kepada manager. Akibatnya adalah para manager yang memiliki kepentingan pribadi memiliki insentif untuk mengambil keputusan dengan cara mengambil alih dana yang ditanamkan pemegangsaham diperusahaan. Para manager dapat melakukan penyalahgunaan dalam berbagai bentuk misalnya membayar kompensasi yang berlebihan, serta melakukan investasi yang memiliki kemungkinan merugian bagi pemegang saham (Jensen dan Meckling, 1976).

Dalam keputusan investasi adalah ketika manajer perusahaan berusaha untuk memaksimalkan investasinya namun tidak sesuai dengan yang diharapkan pemegang saham. Preferensi dari manajer perusahaan juga dapat berbeda dari yang diharapkan pemegang saham. Biddle et al. (2009) menyatakan bahwa adanya moral hazard yang diakibatkan oleh perbedaan insentif antara pemilik dan pengelola peusahaan yang dapat terjadi dalam bentuk overinvestment maupun underinvestment tergantung pada ketersediaan dana diperusahaan.

Efisiensi Investasi. Verdi (2006) suatu perusahaan dikatakan melakukan investasi yang efisien jika perusahaan melakukan semua proyek dan hanya pada proyek dengan NPV (Net Present Value) positif dengan asumsi tidak ada friksi pasar seperti adverse selection dan agency costs. Investasi yang tergolong tidak efisien termasuk underinvestment ketika perusahaan melewatkan kesempatan investasi yang memiliki NPV positif dan juga overinvestment ketika perusahaan melakukan investasi pada proyek yang bernilai NPV negatif. Biddle et al. (2009) menyatakan efisiensi investasi yaitu ketika perusahaan menginvestasikan pada proyek yang bernilai positif (NPV positif), dibawah skenario tidak ada adverse selection.Sedangakan underinvestment dapat dikatakan ketika perusahaan kehilanga suatu proyek yang mendatangkan NPV yang positif, dan overinvestment yaitu ketika perusahaan menginvestasikan pada proyek yang NPV negatif.

Berdasarkan penelitian Lara et al. (2016) masalah underinvestment dan overinestment dapat diatasi dengan konservatisme, karena konservatisme mengakui kerugian lebih cepat dibandingkan laba sehingga keputusan investasi yang tidak menguntungakn bagi pemegang saham akan segera diketahui.Selain itu dalam penelitian 
Lara et al. (2016) juga membuktikan bahwa pengaruh konservatisme terhadap efisiensi investasi semakin besar pada perusahaan yang mengalami asimetri informasi. Sehingga hasil tersebut menunjukan bahwa konservatisme dapat mengatasi masalah keputusan investasi yang tidak optimal, terutama pada perusahaan yang mengalami asimetri informasi yang tinggi. Hasil ii juga didukung oleh penelitian Francis dan Martin (2010) bahwa konservatisme dapat berpengaruh tehadap keputusan investasi akuisisi sehigga pada perusahaan yang cenderung konservatif keputusan investasi akuisisi menunjukan hasil yang positif dan perusahaan cenderung lebih cepat melakukan divestasi atas investai yang tidak menguntungkan.

Motif dalam Merger dan Akuisisi. Ada tiga motif utama perusahaan melakukan merger dan akuisisi yaitu synergy, managerialism dan hubris. Ketiga motif ini menjelaskan mengapa perusahaan melakukan Merger dan Akuisisi baik secara domestik maupun crossborder. Merger dan Akuisisi yang dimotivasi oleh motif synergy yaitu ketika nilai dari gabungan dua perusahaan melebihi dari nilai total nilai dari perusahaan-perusahaan secara individu(Seth, 2000). Berdasarkan Roll (1986) hipotesis hubris yaitu merger dan akuisisi terjadi ketika manager membuat kesalahan dalam melakukan evaluasi atas perusahaan yang akan diakuisisi. Motif ketiga yaitu karena adanya kepentingan pribadi dari manager di perusahaan pengakuisisi (Khimaz dan Baker, 2008). Berdasarkan motif managerialism, manager telah mengetahui ketika melakukan merger dan akuisisi perusahaan mengetahui akam membayar lebih dari nilai yang seharusnya atas perusahaan target akuisisi.

Konservatisme. Secara tradisional pengertian konservatisme akuntansi yaitu mengantisipasi tidak adanya laba, tetapi mengatisipasi semua kerugian. Dengan konservastisme akuntansi maka perusahaan memilih metode akutansi dan estimasi yang menjaga nilai buku asset relative rendah (Penman dan Zhang, 2002).Basu (1997) mendefinisikan konservatisme sebagai laba yang merfleksikan periode badnews lebih cepat dibandingkan dengan goodnews. Duellman (2006) menyatakan bahwa setidaknya ada tiga manfaat dari konservatisme yaitu konservatisme dapat mengurangi kemungkinan over-compensation terhadap manajemen dengan cara membatasi kemungkinan adanya overstatement asset dan pendapatan. Kedua dengan konservatisme dapat membantu direksi lebih mudah dalam mengidentifikasi proyek-proyek yang memiliki NPV negatif. Ketiga dapat mencegah manajer ex-ante untuk terlibat dalam proyek yang memiliki NPV negatif

Agency Cost. Agency cost muncul ketika kepentingan manager tidak selaras dengan para pemilik perusahaan (pemegang saham) dan manager mengambil preferensi untuk fasilitas pekerjaan, shirking, mengambil keputusan yang berdasarkan kepentingan pribadi dan keputusan yang menguntungkan pada pihak tertentu yang akhirnya dapat mengurangi kesejahteraan pemegang saham (Anget al., 2000). Menurut Ang et al.(2000) agency cost seharusnya berbading terbalik dengan kepemilikan saham utama yaitu jika pemilik saham juga merupakan bagian dari manager perusahaan maka dorongan untuk melakukan tindakan mengambil keuntungan pribadi akan berkurang karena bagian keuntungan yang diperoleh dari perusahaan akan meningkat sesuai dengan kepemilikan sahamnya, selain itu agency cost pada perusahaan yang dikendalikan oleh satu kepemilikan keluarga lebih dari lima puluh persen akan rendah, dan akan meningkat sesuai dengan jumlah pemegang saham yang bukan bagian dari manajemen perusahaan (Ang et.al, 2000). 
Pengembangan Hipotesis. Berdasarkan penelitian $\mathrm{Hu}$ et al. (2015) menunjukan bukti bahwa konservatisme dapat meningkatkan lingkungan pelaporan, karena melalui konservtisme dapat memfasilitasi arus informasi antara insider dan outsider. Konservatisme di dalam perusahaan dapat memebantu mengurangi kemungkinan manager mengambil keputusan yang tidak efisien. Pada perusahaan yang konservatif investasi yang bernilai tidak menguntungkan dapat segera diketahui. Jika manager mengetahui lebih awal bahwa prakiraan kerugian ekonomi yang akan dialami perusahaan, hal ini diharapkan dapat menurunkan kemungkinan manager melakukan keputusan investasi yang dapat mengakibatkan kinerja perusahaan menurun. Peran konservsatisme menjadi penting agar perusahaan mengambil keputusan investasi yang efisien, salah satunya yaitu keputusan dalam merger dan akuisisi.

Meger dan akuisisi merupakan salah satu investasi yang sangat penting bagi perusahaan karena terdapat tujuan strategis yang ingin dicapai. Dalam keputusan ini perusahaan tentu memiliki tujuan-tujuan strategis untuk meningkatkan kinerja dan memperluaas cakupan perusahaan. Lara et. al (2016) menyatakan bahwa konservatisme di perusahaan dapat memicu pengakuan kerugian lebih dini sehingga dapat mengurangi perilaku manager yang mengejar investasi dengan NPV negatif dengan motif menghasilkan keuntungan. Oleh karena itu pada keputusan investasi yang terkait dengan merger dan akuisisi, konservatisme diharapkan dapat mencegah perusahaan mengambil keputusan yang bersifat hubris maupun managerialism, dengan menghindari perusahaan melakukan kesalahan dalam penilaian target akuisisi maupun tindakan manager yang berdasarkan kepentingan pribadi.

H1 : Konservatisme berpengaruh positif terhadap efisiensi investasi pada perusahaan yang melakukan Merger dan Akuisisi.

Perusahaan dengan agency cost yang tinggi maka menunjukan konflik kepentingan dari perusahaan tinggi. Salah satu penyebab tingginya masalah agensi adalah disebabkan oleh asimetri informasi, sehingga kondisi ini dapat memperburuk kondisi overinvestment dan underinvestment yang terjadi hal tersebut disebabkan adanya peluang bagi pihak manager untuk bertindak tidak selaran dengan pemegang saham.Manager dapat mengambil keputusan sesuai kepentingan pribadi dan keputusan yang menguntungkan pada pihak tertentu yang akhirnya dapat mengurangi kesejahteraan pemegang saham (Anget al., 2000).

Ketika konflik ini tinggi maka kemungkinan keputusan untuk melakukan Merger dan Akuisisi yang hanya menguntungkan pihak tertentu akan semakin tinggi. Sehingga perusahaan dengan masalah agensi yang tinggi dapat menyebabkan keputusan investasi tidak efisien. Dengan kondisi ini maka masalah keagenan di perusahaan dapat meningkatkanagency cost. Pada perusaaan dengan ageny cost yang tinggi maka dapat memperlemah pengaruh konservatisme terhadap efisiensi investasi.

H2: Agency cost dapat memperlemah pengaruh positifkonservatisme terhadap efisiensi investasi perusahaan yang melakukan Merger dan Akuisisi.

\section{METODE}

Populasi dan Sampel. Populasi penelitian ini adalah semua perusahaan yang terdaftar pada masing-masing pasar modal di beberapa negara ASEAN yaitu Indonesia, Malaysia, Singapura, Thailand, Filipina dan Vietnam. Sampel ditentukan dengan menggunakan metode purposive sampling, dengan kriteria: (a) Perusahaan melakukan aktivitas Merger 
atau Akusisi pada tahun 2012-2016; (b) Data-data mengenai variabel penelitian yang akan diteliti tersedia lengkap dalam laporan tahunan perusahaan yang diterbitkan pada periode penelitian yaitu 2011-2016

Variabel dan Pengukuran Variabel Penelitian yang akan dilakukan ini menggunakan satu variabel yaitu variabel terikat (dependent) dan variabel bebas (independent). Variabel terikat merupakan variabel yang dijelaskan atau dipengaruhi oleh variabel bebas. Variabel terikat yang digunakan dalam penelitian ini adalah efisiensi investasi. Sedangkan variabel bebas merupakan variabel yang diduga mempengaruhi variabel terikat. Variabel bebas dalam penelitian ini meliputi koservatisme. Variabel moderasi pada penelitian ini yaitu agency cost.

Pada penelitian ini variabel dependen yang diteliti yaitu efisiensi investasi. Menurut Biddle (2009) investasi yang efisien yaitu jika perusahaan berinvestasi pada investasi yang memiliki NPV positif. Pengukuran efisiensi investasi pada penelitian ini mengacu pada penelitian sebelumnya Chen et. al(2011). Efisiensi investasi adalah deviasi dari model investasi yang merupakan fungsi dari growth opportunities. Model investasi ini diestimasi secara cross-section per industri masing-masing negara, dengan setiap industri minimal sepuluh perusahaan pada tiap negara. Hasil dari regresi ini diperoleh nilai residu yang merupakan penyimpangan dari investasi atau inefisiensi investasi. Dari nilai residu tersebut diubah menjadi nilai absolut kemudian dikalikan dengan minus satu. Hasil dari nilai tersebut menunjukan semakin tinggi nilai maka semakin tinggi tingkat efisiensi investasi.

Sehingga model pengukuran untuk efisiensi investasi pada penelitian Chen et. al(2011) yaitu dengan melakukan regresi dari model berikut:

$$
\begin{aligned}
& I_{i, t+1}=\alpha_{0}+\alpha_{1} N E G_{i, t}+\alpha_{2} R E V-G R O W T H_{i, t}+\alpha_{3} N E G_{i, t} \\
& R E V=G R O W T H_{i, t}+e_{i, t}
\end{aligned}
$$

Keterangan : $I=$ Total investasi perusahaan $i$ pada tahun $t+1$, yaitu total capital expenditure pada perusahaan $i, t+1$ dibagi dengan total aset pada perusahaan $i, t ; N E G=$ indikator nilai 1 jika perusahaan $i, t$ memiliki pertumbuhan pendapatanyang negatif dan 0 untuk lainnya; $R E V-G R O W T H=$ prosentase pertumbuhan pendapatan tahunan perusahaan $i, t$.

Variabel independen Konservatisme $(C O N-A C C)$ menggunakan pengukuran konservatisme berbasis akrual (accrual-based). Pengukuran konservatisme akrual mengacu pada pengukuran yang digunakan oleh penelitian sebelumnya Givoly dan Hyan (2000), Ahmed dan Duellman (2007), Qiang (2007). Konservatisme akan mengakibatkan akrual menjadi negatif, maka semakin besar nilai negatif artinya semakin konservatif suatu laporan keuangan. Pengukuran konservatisme akrual Ahmed dan Duellman (2007) yaitu rata-rata dari akrual selama tiga tahun dibagi dengan -1. Akrual dihitung dari laba sebelum item luar biasa ditambah penyusutan dikurangi dengan arus kas dari aktivitas operasi dibagi dengan rata-rata total asset. Pengukuran konservatisme menggunakan nilai rata-rata selama tiga tahun dengan $t$ sebagai nilai tengah, dibagi dengan rata-rata total asset dan dikalikan dengan negatif satu. Semakin tinggi nilai hasil pengukuran menunjukan semakin tinggi tingkat konservatif suatu perusahaan.

$$
C O N-A C C=\frac{\text { laba sebelum item luar biasa }+ \text { peryusutan- arus kas dari altivitas operasi }}{\text { rata-rata total asget }}
$$


Pengukuran agency cost yang kedua yaitu menggunakan asset utilization ratio. Pengukuran ini mengacu pada penelitian Ang et al. (2000), asset utilization diukur dari rasio total penjualan dibagi dengan total asset. Rasio ini menunjukan kemampuan manager menggunakan asset di perusahaan secara efisien. Semakin tinggi rasio ini menunjukan semakin efisien dalam mengelola asset yang dapat meningkatan nilai bagi pemegang saham, begitu juga sebaliknya (Singh et al. 2003).

asset utilization ratio total penjualan $_{i, t}=\frac{\text { total asset }}{i, t}$

Keterangan:

Total penjualan $\quad:$ total penjualan perusahaan $i$ pada tahun $t$.

Total asset : total assetipadatahun $t$

Untuk menguji hipotesis, penelitian ini mengacu pada model penelitian yang dilakukan oleh Lara et. al (2016) mengenai konservatisme dan efisiensi investasi

Model 1 Pengaruh Konservatisme terhadap Efisiensi Investasi

InvEff int $_{t+1}=\beta_{0}+\beta_{1}$ CONS $-A C C_{i, t}+\beta_{2}$ AgencyCost $+\beta_{\mathrm{s}}$ SIZE $E_{i, t}+$

$\beta_{6}$ CFOSale $+\beta_{7}$ Tang $+\beta_{8}$ LOSS $+\beta_{9}$ GDP $+e_{i, t}$

Model 2 Pengaruh Agency Cost terhadap hubungan Konservatisme dan Efisiensi Investasi InvEff $_{i, t+1}=\beta_{0}+\beta_{1}$ CONS $-A C C_{i, t}+\beta_{2}$ AgencyCost i $_{i, t}+\beta_{3}{\text { CONN }-A C C_{i, t}}$ *

AgencyCost $t_{i, t}+\beta_{4}$ SIZE $E_{i, t}+\beta_{5}$ CFOSale $+\beta_{6}$ Tang $+\beta_{7}$ Loss $+\beta_{8}$ GDP $+e_{i, t}$

Keterangan: InnEff $=$ efisiensi investasi perusahaan $\mathrm{i}$ pada tahaun $\mathrm{t}+1$, variabel ini menunjukan kinerja investasi perusahaan nilai InnEff diperoleh dari regresi model investasi; CONN_ACC = konservatisme perusahaan i pada tahun $\mathrm{t}$; AgencyCost $=$ agency cost persusahaan $\mathrm{i}$ pada tahun $\mathrm{t}$. Variabel kontrol (CFOSale $=$ rasio arus kas operasi dengan penjualan; Size $=$ ukuran perusahaan i pada tahun $t$; Tang $=$ rasio asset tetap terhadap total asset perusahaan i pada tahun $\mathrm{t}$; Loss $=$ merupakan dummy variabel yang menjukan posis keuangan perusahaan i pada tahun $t$, dinyatakan 1 jika perusahaan mempunya laba sebelum extraordinary item; GDP = :merupakan variabel yang menunjukan besarnya produk domestik bruto dari Negara perusahaan terdaftar. Variabel GDP diukur dengan log GDP per kapita).

\section{HASIL DAN PEMBAHASAN}

Berdasarkan proses pengumpulan sampel diperoleh data sampel sejumlah 389 perusahaan yang melakukan merger dan akuisisi tahun 2012-2016 yang memenuhi kriteria. Statistik deskriptif setiap variabel pada penelitian ini terdapat pada tabel 1. Hasil Statistik Deskriptif. Analisis statistik deskriptif merupakan gambaran dari data-data variabel independen dan dependen pada penelitian ini.

Pada Tabel 1 diketahui variabel dependen efisiensi investasi (Inn_Eff) memiliki nilai rata-rata $-0,03$ dan standar deviasi yaitu 0,02 . Nilai tersebut menunjukan bahwa efisiensi investasi pada perusahaan yang melakukan Merger dan Akuisisi pada penelitian ini cukup tinggi sehingga memiliki nilai rata-rata mendekati nol yaitu -0.03 . Terdapat perusahaan yang efisien dalam mengelola investasinya terbukti dengan nilai maksimal sebesar 0 . 
Variabel independen yaitu konservatisme (Cons_acc) memiliki nilai rata-rata yaitu $-0,17$ dan nilai standar deviasi yaitu 0.88 . Nilai rata-rata konservatisme menunjukan perusahaan pada sampel memiliki konservatisme yang rendah. Hal ini menunjukan bahwa perusahaan cenderung agresif dalam menyajikan laporan keuangan, namun juga terdapat beberapa perusahaan yang konservatif dalam laporan keuangan tinggi hal ini ditunjukan dengan nilai maksimum konservatisme sebesar 0.22 .

Tabel 1. Hasil Statistik Deskriptif

\begin{tabular}{lccccc}
\hline \multicolumn{1}{c}{ Variabel } & Mean & Median & Maximum & Minimum & Std. Dev. \\
\hline INN_EFF & $-0,03$ & $-0,03$ & 0,00 & $-0,08$ & 0,02 \\
CONS_ACC & $-0,17$ & $-0,03$ & 0,22 & $-7,82$ & 0,88 \\
AGENCY & 0,70 & 0,42 & 8,36 & 0,00 & 0,91 \\
COST & & & & & 2641760,00 \\
SIZE & 4.660 .000 .000 & 196.000 .000 & 242.000 .000 .000 & 20500000000,00 \\
CFOSALE & 0.02 & 0,06 & 4,28 & $-5,23$ & 1.30 \\
TANG & 0,22 & 0,16 & 0,89 & 0,00 & 0,21 \\
LOSS & 0,16 & 0,00 & 1,00 & 0,00 & 0,37 \\
GDP & 14293,30 & 10405,12 & 56336,07 & 1542,67 & 17850,88 \\
\hline
\end{tabular}

Variabel AGENCY_ATR yaitu 0.70 dan standar deviasi 0.91. Nilai rata-rata AGENCY_ATR cukup tinggi hal ini menujukan bahwa perusahaan cukup baik dalam mengelola assset yang dimiliki, hal ini menunjukan sebagian besar perusahaan memiliki agency cost yang rendah. Variabel kontrol yang digunakan dalam penelitian ini yaitu ukuran perusahaan, rasio penjualan terhadap aruskas operasi, tangibility, loss serta produk domestik bruto. Nilai rata-rata SIZE yaitu sebesarr USD 4.660.000.000. Nilai rata-rata CFOSALE yaitu rasio arus kas operasi terhadap penjualan sebesar 0.02. Nilai rata-rata TANG 0.22 nilai ini menunjukan rasio asset tetap terhadap total asset perusahaan sebesar $22 \%$. Nilai rata-rata LOSS yaitu 0.16 menunjukan bahwa sebanyak $16 \%$ perusahaan dari seluruh sampel mengalami kerugian. Nilai rata-rata GDP per kapita dalam USD adalah sebesar 14293,30.

Tabel 2. Uji Asumsi Klasik Model 1

\begin{tabular}{llll}
\hline \multicolumn{1}{c}{ Pengujian } & \multicolumn{1}{c}{ Hasil } & \multicolumn{1}{c}{ Kriteria } & \multicolumn{1}{c}{ Kesimpulan } \\
\hline Normalitas & Jarque-Bera 5.240 & Prob. $>0.05$ & Memenuhi normlitas \\
Multikolonieritas & Probability 0.073 & & \\
& CONS_ACC: 1.23 & Vif $<10$ & $\begin{array}{l}\text { variabel independen } \\
\text { bebas } \\
\text { multikolonieritas }\end{array}$ \\
& AGENCY_COST: 1.16 & & \\
& TANG: 1.10 & & \\
& LOSS: 1.15 & & \\
& CFOSALE: 1.41 & & \\
& SIZE: 1.18 & & variabel independen \\
Heterokedasitas & GDP: 1.15 & Prob $>0.05$ & Model regresi bebas \\
& Breusch-Pagan-Godfrey & & \\
Autokorelasi & Prob. Chi-Square 0.1344 & & autokorelasi \\
& Breusch-Godfrey Serial & Prob $>0.05$ & \\
& Correlation LM Test: & & \\
\hline
\end{tabular}


Tabel 2 menunjukan asil uji asumsi klasik untuk model 1. Model 1 digunakan untuk pengujian hipotesis 1 . Berdasarkan hasil uji asumsi klasik dapat disimpulkan bahwa model 1 tidak terdapat pelanggaran asumi normalitas, multikolonieritas, heterokedastisitas dan autokorelasi.

Tabel 3. Uji Asumsi Klasik Model 2

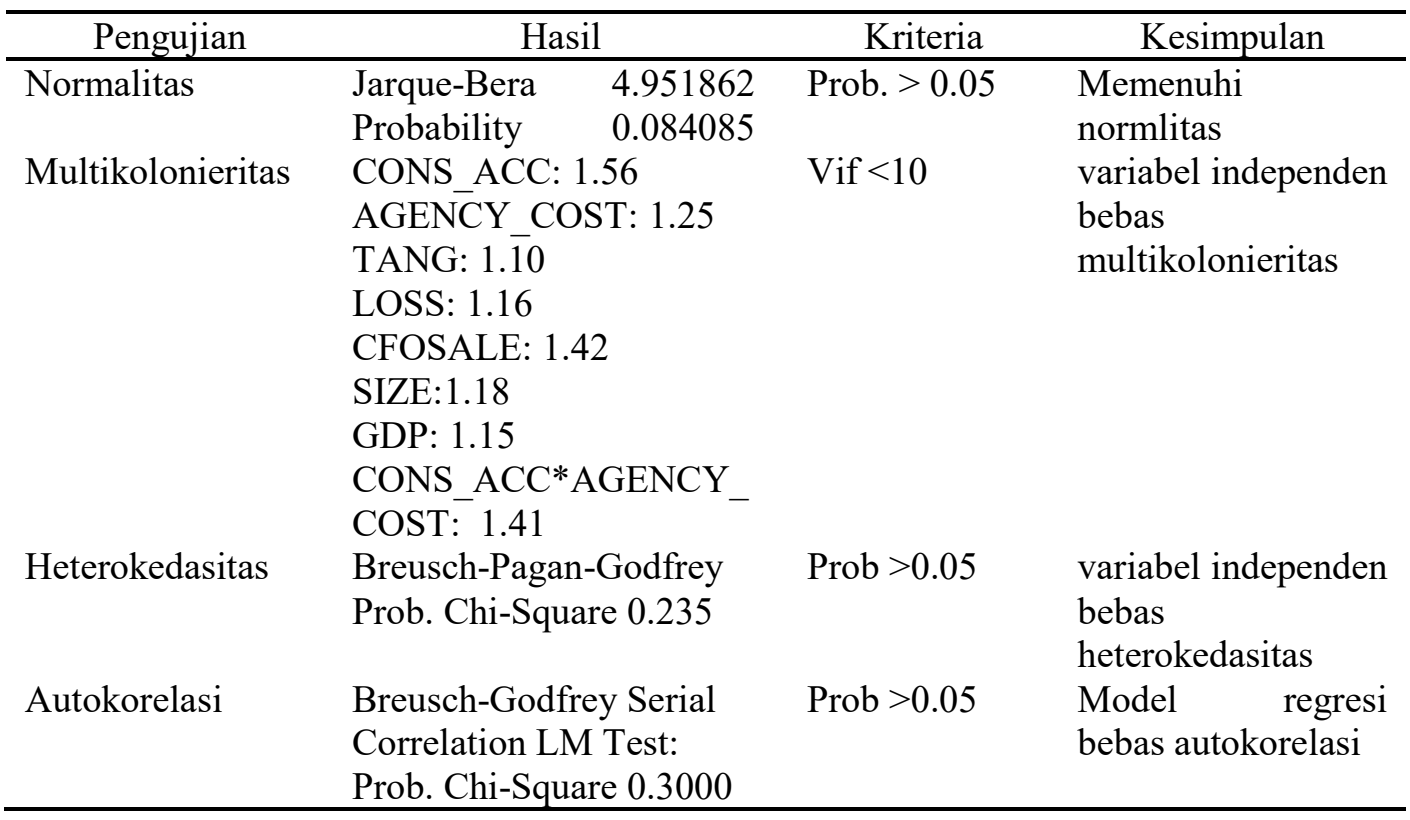

Tabel 3 menunjukan asil uji asumsi klasik untuk model 2. Model 2 digunakan untuk pengujian hipotesis 2 . Berdasarkan hasil uji asumsi klasik dapat disimpulkan bahwa model tidak terdapat pelanggaran asumi normalitas, multikolonieritas, heterokedastisitas dan autokorelasi.

Tabel 4 menunjukan hasil regresi dari model 1 dan 2 untuk menjawab hipotesis 1 dan 2. Hipotesis pertama yaitu konservatisme berpengaruh positif terhadap efisiensi investasi. Hipotesis kedua yaitu agency cost memperlemah pengaruh positif konservatisme terhadap efisiensi investasi. Pada tabel dapa dilihat hasil uji $\mathrm{F}$ statistik menunjukan probabilitas 0,00 yaitu lebih kecil dari alpha $1 \%$. Nilai probabilitas $\mathrm{F}$ statistik tersebut menunjukan bahwa Konservatisme (Cons_Acc) serta variabel kontrol yang digunakan pada model1 mampu menjelaskan secara bersama-sama variabel dependen yaitu Efisiensi Investasi (Inn_Eff). Nilai $\mathrm{R}^{2}$ pada model 1 dan 2 secara berturut-turut yaitu 0,18 dan 018 , artinya variabel independen serta variabel kontrol pada penelitian ini mampu menjelasakan variabel independen sebesar $18 \%$ dan $18 \%$.

Pada Tabel 4 menunjukan bahwa Hipotesis 1 terbukti yaitu konservatisme berpengaruh positif terhadap efisiesi investasi pada perusahaan yang melakukan merger dan akuisisi. Hasil pengujian menunjukan probabilitas CONS_ACC sebesar 0.00 atau kurang dari alpha 1\%. Hasil dari penelitian ini konsisten dengan penelitian sebeumnya yiaut Lara et al. (2016) bahwa konservatisme dapat memiliki peran positif dalam Merger dan Akuisisi. Penelitian ini membuktikan bahwa konservatisme berpengaruh positif terhadap efisiensi investasi perusahaan yang melakukan merger dan akuisisi.

Penelitian ini sejalan dengan penelitian Francis dan Martin (2010) bahwa perusahaan yang konservatif cenderung memiliki kinerja yang lebih baik. 
Tabel 4. Hasil Regresi

\begin{tabular}{lllll}
\hline Variabel & \multicolumn{2}{c}{ Model 1 } & \multicolumn{2}{c}{ Model 2} \\
\hline CONS_ACC & 0.004 & $0.00^{* * *}$ & 0.005 & $0.00^{* * *}$ \\
AGENCY_ATR & -0.002 & $0.03^{* *}$ & -0.002 & $0.01^{* *}$ \\
TANG & -0.008 & $0.02^{* *}$ & -0.007 & $0.03^{* *}$ \\
LOSS & 0.003 & $0.06^{*}$ & 0.004 & $0.05^{*}$ \\
CFOSALE & 0.001 & 0.12 & 0.001 & 0.15 \\
LOG(SIZE) & 0.002 & $0.00^{* * *}$ & 0.002 & $0.00^{* * *}$ \\
LOG(GDP) & 0.002 & $0.01^{* *}$ & 0.002 & $0.01^{* *}$ \\
CONS_ACC*AGENCY_ATR & & & -0.0005 & $0.09^{*}$ \\
Adjusted R-squared & 0.18 & & 0.18 & \\
F-statistic & 13.27 & & 11.84 & \\
Prob(F-statistic) & 0 & & 0 & \\
\hline
\end{tabular}

Pada Francis dan Martin (2010) mebuktikan bahwa pada perusahaan konservatif cenderung memiliki laba dan arus kas yang tinggi setelah akuisisi, dan terjadinya divestasi pasca akuisisi lebih rendah pada perusahaan yang konservatif.

Hasil penelitian ini memmbuktikan bahwa dengan konservatisme perusahaan dapat menekan tindakan oportunis manager dalam keputusan investasi. Pada perusahaan yang konservatif maka kerugian akan lebih cepat diakui daripada laba sehingga perusahaan akan meninggalkan investasi dengan NPV yang negatif. Selain itu konservatisme merupakan salah satu aspek penting dalam menunjang kualitas laporan keuangan (Penman dan Zhang, 2002). Laporan keuangan yang berkualitas merupakan aspek yang penting dalam meningkatkan efisiensi investasi. Biddle et al. (2009) menyatakan bahwa perusahaan yang konservatif cenderung memiliki kualitas laporan keuangan yang baik. Laporan keuangan merupakan alat dalam pengambilan keputusan dan para pemegang saham juga mengawasi kinerja perusahaan melalui informasi yang diperoleh melalui laporan keuangan. Sehingga sangat dibutuhkan kualitas laporan keuangan yang baik dapat mengurangi masalah asimetri informasi yang ada di perusahaan dan informasi yang sampai pada pemegang saham sesuai dengan kondisi yang sebenarnya. Dengan konservatisme perusahaan dapat mengurangi tindak manager yang tidak selaras dengan kepentingan para stakeholder (Biddle et al., 2009).

Hasil pada Tabel 4 menunjukan bahwa Hipotesis 2 ditolak yaitu agency cost tidak terbukti memperlemah pengaruh positif konservatisme terhadap efisiensi investasi. agency cost yaitu merupakan rasio dari total penjualan dengan total asset. Semakin kecil (besar) nilai Agency_Atr maka semakin besar (kecil) agency cost yang ada diperusahaan. Semakin besar rasio ini menunjukan semakin efisien penggunaan asset dalam menghasilkan penjualan sehingga menunjukan agency cost yang lebih kecil. Sehingga ekspektasi hasil pengujian menunjukan koefisien positif yang menunjukan agency cost memperlemah pengaruh positif konservatisme terhadap efisiensi inevstasi. Pada pengujian agency cost yang diukur dengan rasio utilitas asset menunjukan hasil sebaliknya yaitu Agency_Atr menunjukan koefisien negatif signifikan dan interaksi antara variabel Cons_Acc dan $A G E N C Y$ menunjukan koefisien negatif signifikan. Hasil ini berlawanan dengan dengan hipotesis yang menyatakan bahwa pengaruh positif konservatisme terhadap efisiensi investasi semakin kecil (besar) pada perusahaan yang mengalami agency cost yang besar 
(kecil). Hasil pengujian pada kolom A menunjukan bahwa agency cost memperkut berpengaruh positif konservatisme pada efisiensi investasi perusahaan.

Dari hasil pengujian agency cost dapat disimpulkan bahwa hipotesis 2 tidak terbukti memperlemah pengaruh positif konservatisme terhadap efisiensi investasi. Hasil pengujian menunjukan agency cost memperkuat pengaruh positif konservatisme terhadap efisiensi investasi. Hal ini menunjukan bahwa perusahaan dengan agency cost yang tinggi maka perusahaan yang konservatif dapat mengambil keputusan yang lebih efisien. Hal ini dapat disebabkan karena perusahaan-perusahaan yang ada di Asia Tenggara sebagian besar merupakan perusahaan dengan kepemilikan keluarga. Pada perusahaan kepemilikan keluarga memiliki konflik keagenan yang berbeda. Kepemilikan keluarga dapat menurunkan konflik antara pemegang saham dan manager yang lebih rendah hal ini disebabkan para pemilik yang memiliki posisi atau jabatan yang penting di perusahaan, sehingga dapat mengawasi secara lebih baik investasi yang diambil.

Menurut Andhikari dan Sutton (2016) kinerja setelah merger perusahaan kepemilikan keluarga lebih baik dibandingkan dengan perusahaan yang bukan keluarga. Pada perusahaan yang konservatif manager akan lebih berhati-hati dalam mengambil keputusan investasi karena perusahaan akan lebih cepat mengakui kerugian ataupun beban, sehingga ini membuat konservatisme menjadi salah satu mekanisme pengawasan bagi perusahaan ditambah dengan pengawasan dari kepemilikan keluarga terhadap investasi yang diambil sehingga investasi pada perusahaan keluarga menjadi lebih efisien.

\section{PENUTUP}

Simpulan. Hasil penelitian ini yaitu konservatisme berpengaruh positif terhadap efisiensi investasi pada perusahaan yang melakukan merger dan akuisisi. Perusahaan yang koservatif maka cenderung akan lebih efisien dalam mengelola investasinya. Hasil penelitian ini membuktikan bahwa konservatisme memiliki peran yang penting pada laporan keuangan perusahaan sebagai dasar pengambilan keputusan investasi. Ketika perusahaan cenderung konservatif maka akan lebih cepat merespon bad news dan kemungkinan kerugian yang akan terjadi dimasa yang akan datang akan lebih cepat diketahui. Hal ini membuat manager lebih berhati-hati dalam mengambi keputusan investasi. Konservatisme menjadi penting dalam perusahaan khusunya pada keputusan merger dan akuisisi karena dengan konservatisme dapat meningkatkan efisiensi investasi, sehingga perusahaan dapat terhindar dari keputusan merger dan akuisisi yang bersifat hubris maupun managerialism.

Hasil penelitian ini menemukan bahwa seara agency cost dapat memperkuat pengaruh positif konservatisme terhadap efisiensi investasi. Hal ini dapat disebabkan karena perusahaan-perusahaan yang ada di Asia Tenggara merupakan perusahaan dengan kepemilikan keluarga yang mengalami masalah agensi berbeda. Kepemilikan keluarga dapat menurunkan konflik antara pemegang saham dan manager yang lebih rendah hal ini disebabkan para pemilik yang memiliki posisi atau jabatan yang penting di perusahaan, sehingga dapat mengawasi secara lebih baik investasi yang diambil.

Penelitian ini memliki keterbatasan yaitu hanya meneliti investasi pada pada perusahaan yang melakukan merger dan akuisisi, sehingga penelitian selanjutnya dapat meneliti tentang aktivitas lain seperti investasi pada riset dan development. Penelitian ini hanya menggunakan satu pengukuran konservatisme yaitu konservatisme akrual, sehingga terdapat kemungkinan pengukuran konservatisme akrual tidak seluruhnya dapat 
menangkap konservatisme di perusahaan, penelitian selanjutnya dapat menggunakan pengukuran konservatisme lainnya seperti pada penelitian Lara et al. (2016).

\section{DAFTAR RUJUKAN}

Ahmed, A. S., \& Duellman, S. (2011). "Evidence on the role of accounting conservatism in monitoring managers? Investment decisions". Accounting \& Finance, 51(3), 609633.

Andhikari, Hari. P. dan Ninon K. Sutto. (2016). “ In the family: The effect of family ownership on acquisition performance". Journal of Economics and Business.

Beaver dab Ryan. (2000). "Biases and Lags in Book Value and Their Effects on the Ability of the Book-to-Market Ratio to Predict Book Return on Equity”. Journal of Accounting Research, 38 (01).

Bertrand, Marriane. dan Antoinette Schoar. (2005). "The Role of Family in Family Firm”. Journal of Economic Perspectives, 20 (2).

Biddle G.C., Hilary G., Verdi R.S., (2009). "How does financial reporting quality relate to investment efficiency? ”. Journal of Accounting and Economics, 48, 112-131.

Basu, Sudipta. (1997). "The Conservatism Principle and The Asymetric Timeliness of Earnings". Journal of Accounting and Economics, 24, 3-37.

Bushman dan Smith. (2001). "Financial accounting information and corporate governance". Journal of Accounting and economics. 32, 237-333

Cleassens, Stjin. et al., (2000). "The Separation of Ownership and Control in East Asian Corporation”. Journal of Financial Economics, 58.

Chakrabakti, Rajesh; Swasti Gupta-Mukherjee; Narayanan Jayaraman. (2009). "Marsvenus marriages: Culture and Cross-border M\&A". Journal of International Business Studies, 40, 216-236.

Duellman, Scott,. (2006). Evidence on the Role of Accounting Conservatism in Corporate Governance: Disertation Syracuse University.

Datta Deepak K. dan George Puia. (1995). "Cross-Border Acquisitions: An Examination of the Influence of Relatedness and CulturalFit". MIR: Management International Review, 35 (4), 337-359.

Gugler dan Yutoglu, (2003). "Corporate Governance and Dividend Pay-out Policy in Germany”. European Economic Review, 47, 731-758.

Healy dan Palepu (2001). "Information asymmetry, corporate disclosure, and the capital markets: A review of the empirical disclosure literature". Journal of Accounting and Economics, 31, 404-440.

$\mathrm{Hu}$ et al. (2014). "Does accounting conservatism improve the corporate information environment?". Journal of International Accounting, Auditing and Taxation, 23, 3243.

Ang, James et. al. , (2000). “Agency Cost and Ownership Structure”. The Journal of Finance, 55, 81-106.

Jensen dan Meckling. (1976). "Theory of the Firm: Managerial Behavior, Agency Costs and Ownership Structure". Journal of Financial Economics, October, 3 (4), $305-$ 360.

Kaplan, Steven N. (2997). "Do Investment Cash Flow Sensitivitas Provide Useful Measures of Financial Constraints?". The Quarterly Journal of Economics, 112, 169-215. 
Kim, Keehwan. Ohjin Kwon . (2015). “The Investment Efficiency Of Private And Public Firms: Evidence From Korea”. The Journal of Applied Business Research, 31.

Lara et al. (2016). "Accounting Conservatism and Firm Investment Efficiency". Journal of Accounting and Economics, 61, 221-238.

LaFond dan Watts. (2008). The Information Role of Conservatism. The Accounting Review. 82, 447-478.

Lin et al. (2014). The relations among accounting conservatism, institutional investors and earnings manipulation. Economic Modelling, 37, 164-174.

Madura, Jeff dan Jurica Susnjara. (2013). "The appeal of private targets in international acquisitions”. Journal of International Financial Markets, Institutions \& Money 24,198- 222 .

Penman dan Zhang. (2002). "Accounting Conservatism, the Quality of Earnings, and Stock Returns". The Accounting Review.

Roychowdhury , Sugata, Ross L. Watts. (2007). "Asymmetric timeliness of earnings, market-to-book and conservatism in financial reporting". Journal of Accounting and Economics, 44, 2-31.

Xie, Jun. (2015). "CEO career concerns and investment efficiency: Evidence from China”. Emerging Markets Review, 24, 149-159.

Wan et al., (2015). "Career concerns, shareholder monitoring and investment efciency: From the perspective of compensation contract rigidity in Chinese SOEs". Chine Journal of Accounting Research, 8, 59-73.

Zhang, Jieying (2008). "The contracting benefits of accounting conservatism to lenders and borrowers". Journal of Acounting and Economics, 45.

Arifin, Zaenal. (2003). "Masalah Agensi dan Mekanisma Kontrol Pada Perusahaan Dengan Struktur Kepemilikan Yang Dikontrol Keluarga: Bukti Dari Perusahaan Publik di Indonesia”. Disertasi. Depok.Universitas Indonesia.

Mauludy, Citra Imanda, (2015). "Analisis Pengaruh Kualitas Pelaporan Keuangan, Debt Maturity, dan Foreign Ownership terhadap Efisiensi Investasi pada Perusahaan NonKeuangan di Indonesia". Skripsi. Depok.Universitas Indonesia.

Verdi. (2006). Financial Reporting Quality and Investment Efficiency. Available at paper.ssrn.com.

Zhai dan Wang. (2016). "Accounting information quality, governance eficiency and capital investment choice”. China Journal of Accounting Research, 9, 251-266.

Zhang dan Penman (2002). "Accounting Conservatism, the Quality of Earnings, and Stock Returns". The Accounting Review, 77, 237-264.

Zhu et al. (2011). A New Measure for Shareholder Value Creation and the Performance of Mergers and Acquisitions. diperoleh 26 Juni 2018. https://pdfs.semanticscholar.org/f96b/241efa48f9de0420b52bb87970c2201faf4f.pdf 